ISSN 2077-1827. Гуманізація навчально-виховного процесу. 2020, №. 1 (99)

РОЗДІЛ. ПСИХОЛОГІЯ

УДК 159.9:613

\title{
СЕДАШЕВА Світлана
}

кандидат педагогічних наук, доцент кафедри практичної психології, Державного вищого навчального закладу «Донбаський державний педагогічний університет»

вул. Г. Батюка, 19, м. Слов'янськ, Донецька область, Україна, 84116

E-mail:ssveta-76@ukr.net

\section{СЕДАШЕВ Ярослав}

студент спеціальності 014 Середня освіта (Мова і література (англійська, німецька) Державного вищого навчального закладу «Донбаський державний педагогічний університет»

вул. Г. Батюка, 19, м. Слов'янськ, Донецька область, Україна, 84116

E-mail: ssveta-76@ukr.net

\section{ПСИХОЛОГІЧНІ АСПЕКТИ ЗДОРОВОГО СПОСОБУ ЖИТТЯ}

Анотація. Статтю присвячено проблемі психологічних умов формування здорового способу життя. У роботі розкрито сутність понять здоровий спосіб життя, внутрішня картина здоров'я, мотивація, формування мотивації до здорового способу життя.

Автори наголошують, що метою формування здорового способу життя $\epsilon$ сприяння досягненню, в широкому розумінні, благополуччя і здоров'я на всіх рівнях і для всіх; а основними механізмами його формування $\epsilon$ створення психологічних умов для окремих осіб, груп людей позитивно впливати на проблеми здоров'я.

У статті проаналізовано ціннісну природу здорового способу життя, іiі норми; розглянуто принципи формування здорового способу життя.

Розглянуто основні компоненти або складові здорового способу життя. Але вони не є рівнозначними. Якщо для оцінки фізичного здоров'я людини використовуються інформативні методики, які в залежності від віку, статі, фізичного стану, функціональних можливостей організму, рівня підготовленості дозволяють віднести кожного індивіда до одного з рівнів фізичного розвитку, то для психічного, духовного і соціального здоров'я методи кількісних оцінок поки тільки напрацьовуються. Пріоритетним напрямом формування здорового способу життя визначено формування відповідального ставлення до свого здоров'я, усвідомлення та розуміння переваг, які забезпечує здоровий спосіб життя.

У статті узагальнено, що стан здоров'я людини залежить не тільки від біологічних факторів, навколишнього та соціального середовища, а й від ціннісного ставлення людини до власного здоров'я. Розкривається основний зміст проблеми формування позитивної мотивації до ведення здорового способу. У процесі теоретичного аналізу виявлено основні чинники та умови формування мотивації. Було запропоновано ряд заходів, за допомогою яких рівень мотивації значно зросте, як наслідок ми зможемо підвищити рівень здоров'я нації.

Ключові слова: людина, здоров'я, здоровий спосіб життя, цінності, мотивація, психологічні аспекти.

(C) Седашева С., Седашев Я., 2020 
Постановка проблеми у загальному вигляді та ії̈ зв'язок з важливим науковими чи практичними завданнями. Останніми роками якісно нові завдання, пов'язані 3 активізацією реформаторського та євроінтеграційного процесу в Україні, зумовили посилення вимог до стану та умов формування здоров'я населення.

Прийнято вважати, що здоров'я - це перша і найважливіша потреба людини, яка визначає його здібність до праці і забезпечує гармонійний

розвиток особистості. Воно є найважливішою передумовою до пізнання оточуючого світу, до самоутвердження та щастя людини. Здоров'я - безцінний капітал не тільки окремої людини, але й народу, нації, держави. Останнім часом світова наука розглядає проблему здоров'я як одну з глобальних, вирішення яких обумовлює не тільки кількісні, а й якісні характеристики його майбутнього розвитку.

Аналіз останніх досліджень і публікацій, в яких започатковано розв'язання даної проблеми $і$ на які спираються автори, виділення невирішених раніше частин загальної проблеми, котрим присвячується означена стаття дозволив 3'ясувати, що існують дослідження присвячені різним аспектам проблеми становленню й розкриттю питань збереження здоров'я та забезпечення здорового способу життя. Дослідженням цієї проблеми займалися Г.Л. Апанасенко, Т.С. Бойченко, О.В. Вакуленко, В.П. Петленко, І.І. Галецька, В.П. Горащук, Л.І. Гриценок, О.В. Губенко, О.Д. Дубогай, І.А. Зязюн, О.М. Кокун, С.В. Кириленко, Н.М. Колотій, С.В. Лапаєнко, А.Е. Лічко, С.Д. Максименко, Г.С. Нікіфорова, Ю.М. Орлова, В.Г. Панок, О.І. Петрик, О.В. Ревуцька, В.В. Рибалко, С.О. Свириденко, Р.І. Сірко, Л.П. Сущенко, T.М. Титаренко, Т.С. Федорченко, Б.Й. Цуканова, Т.С. Яценко та багато інших, праці яких включають аналіз ключових категорій, наукове обгрунтування зумовленості способу життя людини і стану іiі здоров'я, а також узагальнення й аналіз напрацювань учених 3 досліджуваної проблеми.

Формування цілей статті (постановка завдання). Метою статті $\epsilon$ розкрити психологічні аспекти формування здорового способу життя, показати стратегічне значення здорового способу життя для збереження і розвитку нації.

Виклад основного матеріалу дослідження 3 повним обгрунтуванням отриманих наукових результатів. Не викликає жодних сумнівів, що здоров'я - фундаментальна загальнолюдська цінність, яка характеризує не лише ії стан, але й стратегію життя. Ставлення до здоров'я, відповідно точки зору Р. Березовської та Л. Кулікова, являє собою систему індивідуальних виборчих зв'язків особистості з різними явищами навколишньої дійсності, що сприяють або, навпаки, загрожують здоров'ю людей, а також визначену оцінку індивідом свого психічного або фізичного стану.

Слід зазначити, що людина, розуміючи значимість здоров'я для повноцінної своєї життєдіяльності, як це не парадоксально, недостатньо володіє знаннями і навичками його збереження та зміцнення. В якості основних умов збереження здоров'я висуваються рекомендації щодо ведення здорового способу життя: уникнення шкідливих звичок, травмуючих стресових ситуацій та їх впливів, дотримання правил особистої гігієни, раціональне харчування, оптимізація рухового режиму тощо. Дані фактори дозволяють людині підтримувати гомеостаз іiї внутрішнього середовища, фізичне здоров'я. Але всі пропоновані рекомендації носять відносний характер, так як індивіди розрізняються за статтю, індивідуальними особливостями, життєвим досвідом. 
ISSN 2077-1827. Гуманізація навчально-виховного процесу. 2020, №. 1 (99)

РОЗДІЛ. ПСИХОЛОГІЯ

Розвиток особистості визначається способом життя безпосередньо, а опосередковано - через психологічний стиль життєдіяльності. Відповідно, критерії та норма здоров'я у кожної людини і на кожному життєвому етапі можуть бути різними.

Здоров'я на психологічному рівні пов'язане 3 особистістю людини. Психічне здоров'я може бути порушене домінуванням негативних за своєю сутністю рис характеру, дефектами в моральній сфері, неправильним вибором ціннісних орієнтацій тощо. Перехід від психічного до соціального рівня дуже умовний. Психічні властивості особистості не існують поза системою суспільних відносин, у яку вона включена. Людина розглядається на цьому рівні насамперед як істота суспільна. I, відповідно, тут на першому плані - питання впливу соціуму на здоров'я особистості.[3].

У визначенні поняття «здорового способу життя» враховують два відправних фактори - генетичну природу даної людини та тї відповідальність конкретним умовам життєдіяльності. [5].

Здоровий спосіб життя як система складається з багатьох взаємозалежних та взаємозамінних елементів, які спираються на принципи культури харчування, руху, емоцій, взаємовідносин, виховання, а не тільки на дотриманні певних технологій оздоровлення. Визначення поняття здорового способу життя не експертами, а пересічними громадянами дуже різноманітне, але включає деякі спільні риси: оптимальний режим праці і відпочинку, відмова від шкідливих звичок, заняття фізичними вправами і спортом, переживання задоволення i щастя від прожитого дня, екологічна обстановка місця проживання, дотримання особистої гігієни, гігієни харчування тощо.

Здоровий спосіб життя - це такий стиль існування, за якого через застосування певних методів впливу на організм і його оточення, рівень життєздатності організму стає оптимальним, знаходить вияв постійне вдосконалення і використання потенціалу організму без завдання йому шкоди, причому активність організму і його можливості зберігаються до самої старості.

Таким чином, здоровий спосіб життя $\epsilon$ комплексним способом життєдіяльності людей, спрямованим на гармонічну підтримку фізичних, психічних, моральних, соціальних та трудових функцій. У сучасному розумінні уявлення про здоровий спосіб життя відходить від вузького поняття феномена здоров'я, набуває поширення розуміння його як психосоматичного феномена, обов'язково пов'язаного 3 людськими взаємовідносинами, соціальним самовизначенням, 3 рівнем саморегуляції людини, іiі способами виходу 3 конфліктних і психотравмуючих ситуацій.

Виходячи із цього, поняття «здоровий спосіб життя» визначимо таким чином: це частина загальної культури людини, що характеризується високим рівнем спеціальних знань i мотиваційно-ціннісних орієнтації, набутих у результаті виховання.

Так, залучення людини до здорового способу життя потрібно починати із формування в неї мотивації до здоров'я. Турбота про здоров'я, його зміцнення мають стати ціннісними мотивами, що формують, регулюють і контролюють иiі спосіб життя. Ніякі побажання, накази, покарання не можуть примусити людину вести здоровий спосіб життя, охороняти й зміцнювати власне здоров'я, якщо всім цим не управляє його усвідомлена мотивація здоров'я.[2, с.60].

3 психологічної точки зору проблема здорового способу життя висвітлюється через поняття «внутрішньої картини здоров’я» - уявлення про 
ISSN 2077-1827. Гуманізація навчально-виховного процесу. 2020, №. 1 (99)

РОЗДІЛ. ПСИХОЛОГІЯ

свій фізичний стан, що супроводжується своєрідним емоційним, чуттєвим фоном, що загрожують здоров'ю, факторах, способах його збереження i повернення.

На думку В. Ананьєва, внутрішня картина здоров'я - це сукупність інтелектуальних уявлень про здоров'я індивідуума, комплекс емоційних переживань і відчуттів, а так само його поведінкових реакцій. Основою психічного утворення внутрішньої картини хвороби та внутрішньої картини здоров'я є самопізнання індивідуума.[2, с.20].

О. Лісова досліджуючи психологічні особливості внутрішньої картини здоров'я зазначає, що внутрішня картина здоров'я - це суб'єктивне відображення особистістю стану свого здоров'я, що значною мірою визначає психосоматичний потенціал індивіда. Її дослідження показали, що внутрішня картина здоров'я виявляе себе через направляючу, регулятивну, когнітивноструктуруючу, прогностичну, креодизуючу, саногенну та комунікативнооптимізуючу функції. Також зазначаючи, що теоретична модель внутрішньої картини здоров'я представляє даний психологічний феномен як структурно складне динамічне утворення у самосвідомості людини, що містить сенситивний, емоційний, когнітивний i мотиваційно-ціннісний компоненти. Мотиваційний компонент внутрішньої картини здоров'я опосередковується цінністю здоров'я і визначає спосіб життя, спрямований або на збереження, або на руйнування здоров'я.

Так, мотивування до здорового способу життя повинно базуватися насамперед на принципі науковості і доступності знань (адаптація відповідних наукових знань для всіх ланок освіти з урахуванням особливостей різних вікових категорій, взаємозв'язок науки про здоров'я 3 практичним досвідом). Не менш дійовим $є$ принцип, що відображає процес формування здоров'я людини, природних та соціальних умов його збереження і зміцнення, організується як системний процес у логічному зв'язку всіх його етапів, спрямовується на гармонійний і всебічний розвиток особистості. Цей принцип можна вважати принципом системності.

Розвиток мотивації, за даними Є.П. Ільїна, проходить декілька етапів, основними 3 яких $\epsilon$ наступні: 1) виникнення потреби: фізіологічної, психологічної чи соціальної; 2) усвідомлення потреби; 3) постановка цілей (напрямків) дії: людина фіксує, що і якими засобами вона повинна зробити, чого домоглася, що одержати, щоб задовольнити потребу; 4) здійснення дії; 5) повне чи часткове задоволення потреби або іiї неусунення.

Можна зробити висновок, що мотивація до здорового способу життя - це система ціннісних орієнтацій, внутрішніх спонук до збереження, відновлення і зміцнення здоров'я, це бажання зберегти та покращити даний природою потенціал через дотримання норм здорового способу життя. Даний мотив формується тоді, коли у розпорядженні людини є потрібний набір цінностей, що відповідає соціально обумовленим iii потребам. Він формується на основі потреби бути здоровим і $є$ похідним від біологічної потреби самозбереження. Задоволення цієї потреби спрямовує людину на зміцнення здоров'я і $\epsilon$ дієвою силою для оволодіння вміннями та навичками здорового способу життя. спосіб життя є:

Безперечно, критеріями формування позитивної мотивації на здоровий

- на рівні фізичного здоров'я: прагнення до фізичної досконалості, ставлення до власного здоров'я як до найвищої соціальної цінності, фізична розвиненість, загальна фізична працездатність, загартованість організму, дотри- 
ISSN 2077-1827. Гуманізація навчально-виховного процесу. 2020, №. 1 (99)

РОЗДІЛ. ПСИХОЛОГІЯ

мання раціонального режиму дня, виконання вимог особистої гігієни, правильне харчування;

- на рівні психічного здоров'я: відповідність пізнавальної діяльності календарному віку, розвиненість довільних психічних процесів, наявність саморегуляції, адекватна самооцінка, відсутність акцентуацій характеру та шкідливих звичок;

- на рівні духовного здоров'я: узгодженість загальнолюдських та національних морально-духовних цінностей, наявність позитивного ідеалу, працелюбність, відчуття прекрасного у житті, в природі, у мистецтві;

- на рівні соціального здоров'я (соціального благополуччя): сформована громадянська відповідальність за наслідки нездорового способу життя, соціальне орієнтована комунікативність, доброзичливість у ставленні до людини, здатність до самоактуалізації, саморегуляції, самовиховання. Соціальне здоров'я детерміноване характером і рівнем розвитку найголовніших сфер суспільного життя - економічної, політичної, соціальної, духовної, які в реальності діють одночасно, а їх інтегрований вплив визначає стан здоров'я людини [4].

Отже, під здоровим способом життя слід розуміти спосіб життєдіяльності людини, метою якого $\epsilon$ формування, збереження i зміцнення здоров'я. Психологія здоров'я та здорового способу життя включає практику підтримки здоров'я людини протягом усього життя. Головною метою психології здоров'я $\epsilon$ всебічне вдосконалення людини.[1, с.7-9]. Психологія здоров'я та здорового способу життя забезпечує психологічну адаптацію людини в суспільстві, сприяє iii самореалізації, підвищенню якості життя, здійснює психологічну допомогу при завершенні життєвого шляху.

3 цієї причини, проблема здоров'я носить виражений комплексний характер. На ii визначенні зосереджені зусилля багатьох наукових дисциплін. Серед них одне 3 провідних місць по праву належить психології здоров'я та спорту. Здоров'я та спорт тісно пов'язані між собою, адже стан навколишнього середовища, шалений ритм життя і стресові ситуації послаблюють організм людини. Слід зазначити, що проблему формування здорового способу життя без засобів фізичного виховання не розглядає жоден автор. Тому важливо для кожного зміцнювати організм всіма можливими засобами: фізичними вправами, збалансованим харчуванням, загартовуванням. Фізична активність, навіть незначна, бадьорить тіло та допомагає психіці відпочити. Певні види спорту можна використовувати як терапію для роботи над власними емоційними проблемами. Крім цього, спорт загартовує силу волі, підвищує самооцінку, опірність стресам, дозволяє стати мотивованим і працездатним, повернути внутрішню рівновагу. Без перебільшення можна сказати, що психологія здоров'я та спорту сьогодні - це перспективна, швидко розвинена галузь знання, яка передбачає спеціальну підготовку психологів для практичної роботи в цьому напрямку.

Висновки 3 даного дослідження і перспективи подальших розвідок у даному напрямку. Ми з'ясували, що здоровий спосіб життя сприяє зміцненню здоров'я людини за допомогою певних профілактичних заходів. Ведення здорового способу життя повинне бути ціллю кожної людини.

Наприкінці відзначмо, що очевидною $є$ як теоретична значимість дослідження, присвяченого аналізу такої категорії, як здоровий спосіб життя, так і його практична роль для можливої подальшої роботи у напрямі формування адекватних поглядів на здоровий спосіб життя шляхом створення відповідної 
ISSN 2077-1827. Гуманізація навчально-виховного процесу. 2020, №. 1 (99)

РОЗДІЛ. ПСИХОЛОГІЯ

установки. Формування установки на здоровий спосіб життя - тривалий i багатоаспектний процес.

Дискусійним залишається питання впровадження здорового способу життя, а саме: навчити формувати і берегти власне здоров'я, творчо ставитися до процесу самовдосконалення, як обов'язкової умови повноцінного здорового життя. Адже, якщо кожна особистість буде вести здоровий спосіб життя, то тоді все наше суспільство буде здоровим.

\section{СПИСОК ВИКОРИСТАНОЇ ЛІТЕРАТУРИ}

1. Ананьев В. А. Основы психологии здоровья. Кн. 1. Концептуальные основы психологии здоровья. Санкт-Петербург: Речь, 2006. 384 с.

2. Бароненко В.А., Рапопорт Л.А. Здоровье и физическая культура студента: учеб. пособие. Москва: Альфа - М, 2003. 417с.

3. Галецька Інна, Сосновський Титус. Психологія здоров'я: теорія i практика. Львів: Вид. центр ЛНУ ім. І. Франка, 2006.338 с.

4. Копа В. М. Механізм реалізації соціокультурного ідеалу здоров'я Мультиверсум. 3б. наук. пр. / Ін т філософії НАН. Філософський альманах. Київ: Центр духовної культури. 2004. Вип. 39. С.237.

5. Психологія здоров'я людини/за ред. І. Я. Коцана. Луцьк: РВВ «Вежа»:Волин. нац. ун-ту ім. Лесі Українки, 2009.316 с.

6. Психология здоровья: учебник для вузов / под ред. Г. С. Никифорова. Санкт-Петербург:Питер. 2006. 607 с.

Стаття надійшла до редакції 27.12.2019.

\section{СЕДАШЕВА Светлана}

кандидат педагогических наук, доцент кафедры практической психологии, Государственного высшего учебного заведения «Донбасский государственный педагогический университет»

ул. Г. Батюка, 19, г. Славянск, Донецкая область, Украина, 84116

E-mail: ssveta-76@ukr.net

\section{СЕДАШЕВ Ярослав}

студент специальности 014 Среднее образование (Язык и литература (английский, немецкий) Государственного высшего учебного заведения «Донбасский государственный педагогический университет»

ул. Г. Батюка, 19, г. Славянск, Донецкая область, Украина, 84116

E-mail: ssveta-76@ukr.net

ПСИХОЛОГИЧЕСКИЕ АСПЕКТЫ ЗДОРОВОГО ОБРАЗА ЖИЗНИ

Резюме. Статья посвящена проблеме психологических условий формирования здорового образа жизни. В работе раскрыта сущность понятий здоровый образ жизни, внутренняя картина здоровья, мотивация, формирование мотивации к здоровому образу жизни. В статье проанализировано ценностную природу здорового образа жизни, ее нормы; рассмотрены принципы формирования здорового образа жизни.

Авторы отмечают, что целью формирования здорового образа жизни является содействие достижению, в широком понимании, благополучия и здоровья на всех уровнях и для всех; а основными механизмами его формирования является создание психологических условий для отдельных лиц, групп людей положительно влиять на проблемы здоровья. 
ISSN 2077-1827. Гуманізація навчально-виховного процесу. 2020, №. 1 (99)

РОЗДІЛ. ПСИХОЛОГІЯ

Рассмотрены основные компоненты или составляющие здорового образа жизни. Но они не являются равнозначными. Если для оценки физического здоровья человека используются информативные методики, которые в зависимости от возраста, пола, физического состояния, функциональных возможностей организма, уровня подготовленности позволяют отнести каждого индивида к одному из уровней физического развития, то для психического, духовного и социального здоровья методы количественных оценок пока только нарабатываются. Приоритетным направлением формирования здорового образа жизни определено формирование ответственного отношения к своему здоровью, осознание и понимание преимуществ, которые обеспечивают здоровый образ жизни.

В статье обобщено, что состояние здоровья человека зависит не только от биологических факторов, окружающей и социальной среды, но и от ценностного отношения человека к собственному здоровью. Раскрывается основное содержание проблемы формирования положительной мотивации к ведению здорового образа жизни.

В процессе теоретического анализа выявлены основные факторы и условия формирования мотивации. Был предложен ряд мер, с помощью которых уровень мотивации значительно возрастет, как следствие мы сможем повысить уровень здоровья нации.

Ключевые слова: человек, здоровье, здоровый образ жизни, ценности, мотивация, психологические аспекты.

\section{SEDASHEVA Svetlana}

Candidate of Pedagogical Sciences, Associate Professor of the Department of Practical Psychology State higher educational institution "Donbass State Pedagogical University"

st. G. Batiuk, 19, Slavyansk, Donetsk region, Ukraine, 84116

E-mail: ssveta-76@ukr.net

\section{SEDASHEV Yaroslav}

student specialty 014 Secondary education (Language and literature (English, German) State higher educational institution "Donbass State Pedagogical University"

st. G. Batiuk, 19, Slavyansk, Donetsk region, Ukraine, 84116

E-mail: ssveta-76@ukr.net

PSYCHOLOGICAL ASPECTS OF A HEALTHY LIFE

Summary. The article is devoted to the problem of psychological conditions of forming a healthy lifestyle. The value nature of a healthy lifestyle and its norms are analyzed; principles of healthy lifestyle formation are considered.

The authors emphasize that the goal of shaping a healthy lifestyle is to promote, in the broadest sense, the well-being and health of all levels and for all; and the main mechanisms for its formation are to create conditions for individuals and groups of people to positively influence at health problems. aspects.

Keywords: human, health, healthy lifestyle, values, motivation, psychological

Abstract. Introduction. The objective of forming healthy way of life is promotion of achieving, in general interpretation, everybody's wellbeing and health on all levels; and the main mechanism of its formation is creation of conditions for certain persons, groups of people, communities for positive influence on healthcare problems.

Analysis of publications made it possible to find out that there are researches devoted to the disclosure of questions of preservation of health and maintenance of a 
ISSN 2077-1827. Гуманізація навчально-виховного процесу. 2020, №. 1 (99)

РОЗДІЛ. ПСИХОЛОГІЯ

healthy way of life, which were developed in the works of I. Ivanova, S. Kirilenko, V. Kopy, L. Lepikhova, T. Titarenko, K. Shuliak.

Purpose. The purpose of the article is to reveal the psychological aspects of forming a healthy lifestyle, to show the strategic importance of a healthy lifestyle for the preservation and development of the nation.

The main task of introducing a healthy lifestyle is to learn how to shape and protect your health, to be creative in the process of self-improvement, as a prerequisite for a healthy life.

Results. Health is the greatest value of a person who characterizes not only his condition but also his life strategy. Health is necessary for a person for life, for his realization in it. A surefire way to stay healthy is to be able to shape, preserve and enhance health.

The psychology of health and healthy lifestyles is the science of psychological causes of health, methods and means of its preservation, strengthening and development.

Conclusion. The main components or components of a healthy lifestyle are considered. But they are not equivalent. If informative techniques are used to assess a person's physical health, which, depending on age, sex, physical condition, functional abilities of the organism, level of readiness, allow to attribute each individual to one of the levels of physical development, then for mental, spiritual and social health. quantification methods are yet to be worked out.

\section{REFERENCES}

1. Ananyev V. A. (2006). The basics of the psychology of health. Prince 1. [Osnovы psykholohyy zdorovia]. Textbook for universities. St. Petersburg: Speech. [in Russian].

2. Baronenko V.A., Rapoport L.A. (2003). Student's health and physical education [Zdorove y fyzycheskaia kultura studenta]. Textbook. Allowance. Alfa Moskov. [in Russian].

3. Galecka Inna, Sosnovsky Titus.(2006). Psychology of Health: Theory and Practice. [Psykholohiia zdorovia: teoriia i praktyka]. Lviv: View. Center of LNU im. I. Franka. [in Ukrainian].

4. Kopa V. M. (2004). Mechanism for realizing the social and cultural ideal of health [Mekhanizm realizatsii sotsiokulturnoho idealu zdorovia]. Multiversum. Philosophical Almanac / IN t Philosophy of NAS of Ukraine Zb. sciences. pr. Kiev: Center for Spiritual Culture. VIP. 39. [in Ukrainian].

5. Kotsan I. Ya. (2011). The Psychology of Health's People. [Psykholohiia zdorovia liudyny]. Lutsk: RVV «Vezha»\|Wolin. nat. un-tu im. Forests of Ukraine. [in Ukrainian].

6. Nikiforov G.S. (2003). Psychology of health [Psykholohyia zdorovia]Textbook. for university students studying in the direction and specialties of psychology. - St. Petersburg: Peter .[in Russian].

(переклад на англ. мову зроблено С.О.Мороз - кандидатом філологічних наук, викладачем циклової комісії професійно-орієнтовних дисциплін Державного вищого навчального закладу «Слов'янський коледж транспортної інфраструктури»). 